\title{
Agama, Konflik dan Integrasi Sosial Refleksi Kehidupan Beragama di Indonesia: Belajar dari Komunitas Situbondo Membangun Integrasi Pasca Konflik
}

\author{
Pdt. Retnowati
}

Universitas Kristen Satya Wacana

Naskah diterima 10 Okt 2018, direvisi 21 Nov 2018, disetujui 15 Jan 2018

Abstract The research discusses the settlement effort and reconciliation postriot in Situbondo, East Java. The settlement effort and reconciliation have been carried out by community in Situbondo, especially Islamic and Christian Community to build integration in Situbondo community. To get the data on the role of religious community in this case Islam and Christian as well as the community in Situbondo in general, is got through interview, survey initiated by light observation before doing research. The secondary data is got through review of literature relevant to research problems. Conflict theory, social integration, and re conciliation are used to explain and analyze research problems based on the data gathered. The finding shows that the integration in Situbondo community and reconciliation effort have been carried out by religious community, Islam, Christian and the whole community of Situbondo. The local wisdom of community in Situbondo serves as social capital in manifesting integration in the community so in the post conflict the life of Situbondo community and the relation between religious community in Situbondo experienced the inconveniences can harmonious again.

Keywords: conflict, social integration, and religious community

Abstrak Penelitian ini menyangkut upaya penyelesaian dan rekonsiliasi pasca kerusuhan di Situbondo Jawa Timur. Telah dilakukan upaya-upaya penyelesaian konflik dan rekonsiliasi dari seluruh warga masyarakat Situbondo dalam hal ini umat beragama Islam dan Kristen untuk membangun integrasi dalam masyarakat Situbondo. Untuk mendapatkan data tentang peran umat beragama dalam hal ini Islam dan Kristen serta masyarakat Situbondo secara umum dilakukan melalui metode wawancara, pengamatan yang didahului dengan obeservasi 
ringan sebelum dilakukan penelitian. Data sekunder dilakukan mengkaji pustaka dan dokumen yang relevan dengan masalah penelitian. Teori konflik, integrasi sosial dan rekonsiliasi digunakan untuk menjelaskan dan menganalisa masalah penelitian berdasarkan data-data yang telah diperoleh di lapangan. Hasil penelitian menunjukkan bahwa integrasi dalam masyarakat Situbondo dan upaya rekonsiliasi telah dilakukan oleh masyarakat dan umat beragama di Situbodo. Kearifan lokal yang dimiliki masyarakat Situbondo menjadi modal sosial dalam mewujudkan integrasi dalam masyarakat sehingga pasca kerusuhan kehidupan masyarakat dan hubungan antarumat beragama di Situbondo yang mengalami keretakan dapat dipulihkan kembali.

Kata kunci: konflik, integrasi sosial dan umat beragama.

\section{A. PENDAHULUAN}

Konflik sebagai kategori sosiologis bertolak belakang dengan pengertian perdamaian dan kerukunan (Hendropuspito, 1984:151). Yang terakhir ini merupakan hasil dari proses assosiatif, sedangkan yang pertama dari proses dissosiatif. Proses assosiatif adalah proses yang mempersatukan dan proses dissosiasif sifatnya menceraikan atau memecah. Konflik dan kerukunan atau perdamaian sebagai fakta sosial melibatkan minimal dua pihak (golongan) yang berbeda agama. Konflik menunjuk pada hubungan antara individu dan atau kelompok yang sedang bertikai, sedangkan perdamaian atau kerukunan menunjuk pada hubungan baik antara individu atau kelompok.

Dalam kehidupan beragama sering terjadi friksi, konflik, pertikaian antar umat beragama yang disebabkan oleh berbagai alasan yang bukan saja berkaitan dengan persoalan doktrin agama, namun juga berkaitan dengan masalah di luar agama seperti persoalan ekonomi, sosial, budaya dan politik. Dalam kehidupan beragama di Jawa Timur dalam kurun waktu 10 tahun terakhir sering terjadi berbagai persoalan menyangkut hubungan antar umat beragama. Dalam kasus pertikaian atau konflik antar umat beragama di Situbondo telah mengakibatkan kerugian yang 
sangat besar, bukan hanya infratrusktur, tetapi juga menyisakan trauma yang mendalam bagi warga masyarakat dan umat beragama yang terlibat konflik. Selain itu konflik antarumat beragama juga menghasilkan berbagai persoalan baru yang merusak kehidupan dan keharmonisan antarumat beragama bahkan tatanan dalam masyarakat Situbondo dan sekitarnya.

Belajar dari pengalaman Jawa Timur, khususnya Situbondo hubungan antar agama yang pernah mengalami berbagai persoalan dan konflik yang menyebabkan rusaknya hubungan kedua agama, dalam hal ini islam dan kristen tidak berakhir dengan kehancuran, namun justru memberi ruang dan waktu kedua umat beragama untuk melakukan instropeksi dan saling mengenal kepelbedaan masing-masing agama.

Konflik antar umat beragama di Situbondo ternyata dapat dikelola dan diselesaikan, dan bukan hanya itu kedua umat beragama yang saling bertikai telah berhasil membangun kehidupan bersama sebagai komunitas beragama di tengah masyarakat. Berbagai kerjasama sosial dan kegiatan dilakukan untuk meningkatkan persaudaraan. Tentu upaya pemulihan dan rekonsiliasi ini bukan perkara yang mudah, tetapi membutuhkan perjuangan, komitmen dan kesadaran bersama sehingga konflik benar-benar dapat diakhiri. Hal ini seperti yang dikatakan Usman bahwa, integrasi bisa saja hidup bersebelahan dengan konflik, bahkan melalui konflik keseimbangan hubungan dapat ditata dan diciptakan kembali. Konsep yang ditawarkan tersebut mengisyaratkan bahwa integrasi tercipta melalui proses yang panjang pasca konflik yaitu melalui, interaksi dan komunikasi yang intensif. Kelompok-kelompok sosial yang berintegrasi membangun social networks dalam suatu unit sosial yang relatif kohesif.

Cara-cara yang dilakukan Situbondo, khususnya oleh umat beragama yang terlibat konflik menarik untuk diteliti yaitu, dengan menggunakan modal sosial yang dimiliki sebagai sarana untuk mewujudkan perdamaian dan intergarsi dalam masyarakat. 
Kearifan lokal yang dimiliki oleh kedua umat beragama yang terlibat konflik menjadi modal sosial yang mendukung dalam terwujudnya integrasi pasca kerusuhan.

Penelitian ini dilakukan di Situbondo Jawa Timur yang pernah mengalami konflik sosial bernuansa agama, mengakibatkan retaknya hubungan antar umat beragama Islam dan kristen serta rusaknya infrastruktur, menimbulkan kerugian sangat besar baik milik pribadi masyarakat maupun pemerintah serta lembagalembaga sosial keagamaan. Kiat-kiat yang dilakukan masyarakat Situbondo mengelola konflik dapat digunakan sebagai model penyelesaian konflik bagi daerah-daerah lain. Mengingat kebutuhan memelihara hubungan baik antarumat beragama paca konflik semakin menjadi kebutuhan di berbagai tempat di Indonesia, maka penelitian ini sangat bermanfaat baik secara teoritis maupun praktis, dalam konteks integrasi sosial menyangkut kehidupan umat beragama. Di Siotubondo warga masyarakat masih memelihara nilai-nilai lokal yang terbukti berhasil digunakan dalam rangka penyelesaian konflik.

Penelitian ini tidak hendak membahas sebab-sebab terjadinya konflik di Situbondo, tetapi upaya integrasi sosial yang dilakukan oleh umat beragama yang terlibat konflik pasca kerusuhan. Namun demikian bukan berarti tidak menjelaskan sama sekali penyebab konflik, karena ketika hendak berbicara integrasi dan rekonsiliasi pasca konflik tidak bisa dilepaskan dari konflik itu sendiri. Dalam hal ini integrasi selalu terkait dengan penyebab konflik karena latar belakang terjadinya konflik akan berpengaruh terhadap bentuk atau model perdamaian yang hendak dibangun. Dengan demikian teori konflik akan digunakan dalam penelitian ini bertujuan untuk analisa data. Berdasarkan latar belakang tersebut di atas maka masalah penelitian yang hendak dijelaskan dalam peelitian ini adalah, bagaimana umat beragama di Situbondo membangun integrasi sosial pasca kerusuhan, dan bagaiaman peran agama dalam integrasi sosial di Situndo. 


\section{Agama dan Konflik Sosial}

Weber dan kaum Weberian (Sanderson,1995) menyatakan fenomena munculnya konflik tidak sekedar disebabkan oleh ketimpangan sumber daya ekonomi atau produksi saja, sebagaimana yang disinyalir oleh berbagai pihak selama ini. Dalam hal ini Weber menekankan bahwa konflik terjadi dengan cara jauh lebih luas dari hal-hal tersebut. Walaupun demikian ia juga mengakui bahwa sumber daya ekonomi merupakan ciri dasar kehidupan sosial. Weber melihat banyak tipe-tipe konflik yang terjadi dalam masyarakat.

Dalam hal ini ia membedakan dua tipe konflik. Pertama, konflik dalam arena politik. Konflik ini tidak hanya didorong oleh nafsu untuk memperoleh kekuasaan atau keuntungan ekonomi oleh sebagian individu atau kelompok. Dikatakan Weber konflik tipe ini tidak hanya terjadi pada organisasi politik formal, tetapi juga dalam setiap tipe kelompok, organisasi keagamaan dan pendidikan. Kedua, konflik dalam hal gagasan dan cita-cita. Konflik tipe ini ditekankan Weber bahwa individu atau kelompok seringkali tertantang untuk memperoleh dominasi dalam pandangan dunia mereka, baik yang menyangkut doktrin agama, doktrin nilai budaya, filsafat sosial, ataupun konsepsi gaya hidup kultural. Jadi dapat dikatakan di sini di samping kesenjangan ekonomi masih banyak faktor lain yang bisa menyebabkan terjadinya konflik dalam masyarakat. Seperti yang dikatakan Robertson(1998) konflik dapat pula ditimbulkan oleh agama.

Dalam hal ini Dhurkeim menguatkan, meskipun agama dalam tingkat sosial berfungsi sebagai integrasi kelembagaan masyarakat, tetapi fungsi agama sebagai integrasi kelembagaan masyarakat pada tingat individu bukannya tidak pernah menimbulkan masalah, karena kebutuhan masing-masing warga masyarakat yang tidak seragam sehingga kemungkinan yang timbul dalam persamaan ialah perbedaan kebutuhan masyarakat yang berfariasi yang pada gilirannya bisa menimbulkan konflik. Gejala seperti alienasi yang meluas, sinisme yang meningkat, 
standar moralitas pribadi yang berubah cepat misalnya dalam pola pekerjaan, seks, keluarga dan banyak lagi suara pelbagai kelompok yang mengejar kepentingan ekonominya tanpa memperhatikan kelompok lain juga merupakan keadaan yang oleh Dhurkeim sebagai ancaman konflik sosial yang pada gilirannya dapat menyebabkan integrasi (Johnson, 1986:166).

Dalam hal ini konflik keagamaan dalam kehidupan sosial masyarakat dapat timbul karena perbedaan pemahaman dalam mengintrepetasikan sumber yang dicampuri atau didukung oleh aspek-aspek lain misalnya politik, ekonomi dan sebagainya. Perbedaan tersebut menajam disertai batas-batas yang makin jelas satu sama lain ketika ekonomi dan politik dalam masyarakat mengimplikasi kepelbedaan paham yang ada. Jadi dapat dikatakan di sini bahwa agama dapat pula memberi andil terjadinya pertikaian hubungan antar umat beragama.

Dengan demikian semakin jelas bahwa berbagai masalah sosial dapat menjadi penyebab konflik dalam masyarakat, seperti yang disebutkan Soekamto (1990), sebab-sebab konflik antara lain, (1) perbedaan individu-individu, perbedaan pendirian, sikap dan perasaan bisa melahirkan bentrokan (2) perbedaa kebudayaan. Setiap anggota masyarakat tidak lepas dari pola-pola yang menjadi latar belakang pembentuk serta perkembangan kebudayaan kelompok yang bersangkutan. Perbedaan tersebut dapat disebabkan oleh lingkungan fisik maupun lingkungan sosial budayanya (3) perbedaan kepentingan. Perbedaan ini menyangkut kepentingan ekonomi, politik dan sebagainya (4) perubahan sosial.

Perubahan sosial yang begitu pesat yang didukung globalisasi, modernisasi secara langsung maupun tidak langsung dapat berpengaruh terhadap nilai-nilaii yang ada dalam masyarakat. Sebagian masyarakat tersebut ada yang menerima perubahan, namun ada pula yang tidak siap menerima perubahan. Akibat ketidaksiapan itu dapat memicu konflik dalam masyarakat. Lebih jauh lagi konflik dapat disebabkan oleh perasan curiga antara anggota masyarakat yang saling berinteraksi (Pranomo, 
1998:115). Perasaan curiga ini disebabkan oleh adanya pandangan yang tidak wajar, penuh prasangka, mengenai golongan lain atau stereotype negatif yang telah mendarah daging. Rasa curiga juga disebabkan karena perasaan deterministis hanya pandangan golongan sendirilah yang benar dan golongan lain pada dasarnya buruk, sehingga tidak ada tempat sikap yang menjiwai toleransi.

Mengacu pada pendapat di atas dapat dikatakan bahwa konflik sosial dalam masyarakat dapat disebebakan karena masalahmasalah sosial budaya, idiologi yang tidak sama. Adanya perasaan curiga, tidak senang, cemburu disertai dengan stereotype terhadap individu, kelompok yang berbeda dengan kelompoknya. Dalam hal ini faktor prasangka (predjudice), yaitu sikap negatif terhadap seseorang disebabkan karena kurangnya keterbukaan dan saling mengenal secara benar dan baik antara orang atau kelompok satu terhadap yang lain.

Dari berbagai pengalaman sejarah tentang pertikaian atau konflik antar umat manusia dapat dipastikan bahwa konflik tidak pernah dapat membawa perdamaian dalam hubungan antar individu maupun kelompok. Selanjutnya ketidakdamaian tidak pernah menghasilkan kesejahteraan bagi umat manusia, melainkan melahirkan kekacauan dan ketidaktentraman dalam hidup. Oleh karena itu konflik tidak perlu berkepanjangan melainkan perlu diakhiri dan diselesaikan. Dalam hal ini Simmel dalam Johnson (1994) mengemukakan beberapa cara untuk mengakhiri konflik.

Pertama,menghilangkan dasar-dasar konflik dari tindakan mereka yang terlibat konflik. Kedua, kemenangan pihak yang satu dan kekalahan pihak yang lain. Ketiga, kompromi, keempat, perdamaian. Kelima, ketidakmungkinan untuk berdamai. Dengan demikian meskipun konflik merupakan gejala sosial alamiah namun tidak perlu berkepanjangan. Alasan atau motivasi mengakhiri konflik bisa karena bosan atau lelah atau adanya keinginan untuk mencurahkan tenaganya untuk hal-hal lain. 
Nasikun (1995) menawarkan beberapa cara untuk pengendalian konflik, pertama, melalui konsiliasi yaitu, pengendalian konflik yang terwujud melalui lembaga-lembaga tertentu yang memungkinkan tumbuhnya pola diskusi dan pengambilan keputusan diantara pihak-pihak yang terlibat konflik mengenai persoalan-persoalan yang dipertentangkan melalui cara-cara yang bersifat damai. Kedua, pengendalian konflik melalui mediasi. Cara ini diperlukan bila pengendalian melalui konsiliasi tidak berhasil. Pengendalian konflik melalui jalan mediasi ini dapat dilakukan dengan penunjukkan pihak ketiga yang diharapkan dapat memberi nasehat-nasehat tentang bagaimana orang yang terlibat konflik sebaiknya menyelesaikan konflik di antara mereka. Namun dalam hal ini nasehat pihak ketiga tidak mengikat pihak-pihak yang terlibat konflik, nasehat pihak ketiga ini boleh dilaksanakan atau tidak dilaksanakan. Ketiga, pengendalian konflik melalui cara perwasitan. Jika konflik terus berlanjut, maka dibutuhkan pengendalian konflik melalui cara pewasitan. Melalui cara ini pihak-pihak yang terlibat konflik bersepakat atau terpaksa menerima pihak ketiga untuk memberikan keputusan-keputusan tertentu untuk menyelesaikan konflik yang terjadi, dalam hal ini pihak-pihak yang terlibat konflik berada dalam kedudukan untuk mengambil keputusan-keputusan yang diambil wasit.

Pengendalian atau penyelesaian konflik yang dimaksud di sini bukan merupakan penyelesaian semu, namun yang utama adalah mencari sebab-sebab yang terdalam yang menyebabkan munculnya konflik dipermukaan. Pengendalian konflik ini untuk mencegah timbulnya disintegrasi dalam masyarakat. Asumsinya adalah, jika penanganan konflik ini cukup efektif maka dengan sendirinya akan tercipta integrasi antara kedua kelompok yang terlibat konflik. Namun jika penanganan konflik tidak efektif bukan tidak mungkin konflik atau kerusuhan akan terjadi lagi pada masa-masa yang akan datang.

Selanjutnya agar penyelesaian konflik bukan penyelesaian semu, maka pada pascakonflik perlu dibangun kembali hubungan 
baik antara pihak yang terlibat konflik. Pemulihan hubungan baik ini untuk mengatasi api dalam sekam, agar konflik semacam ini tidak muncul lagi di masa-masa yang akan datang. Dalam hal ini pihak-pihak yang terlibat konflik perlu mengupayakan berbagai langkah untuk mecapai rekonsiliasi. Agar pencapaian rekonsiliasi dapat benar-benar terlaksana dan dapat menemukan maknanya, maka ada beberapa syarat yang harus dipenuhi.

Pertama, pelaku atau korban harus ditemukan atau diakui oleh hukum dan masyarakat. Kedua, Keadilan harus ditegakkan berarti dilaksanakan restribusi (sanksi hukum) terhadap pelaku dan restribusi (pemulihan) terhadap korban. Ketiga, pemisahan antara pengampunan dan kepastian hukum. Keempat, bila hukum positif yang berlaku tidak memiliki pasal-pasal yang mengatur dan memberi sanksi pelanggaran, maka penyelesaian harus mengacu ke prinsip epikeia (yang benar dan adil). Selanjutnya masalah restitusi (pemulihan) terhadap korban juga tidak bisa diabaikan, trauma, kerugian fisik, material maupun mental dari korban merupakan luka-luka yang sulit untuk disembuhkan, bahkan akan terus menerus membekas dan memerlukan pemulihan.

Karena itu luka-luka dan penderitaan korban perlu disembuhkan dengan dilakukan rekonsiliasi. Dalam hal ini aspek keadilan (restitusi) sungguh-sungguh harus dijalankan agar rekonsiliasi dapat merupakan penyembuhan dan pendamaian bagi pihak yang terlibat konflik. Pertanyaannya, apakah rekonsiliasi pasca konflik benar-benar telah terjadi dalam persoalan yang terjadi dalam kehidupan beragama. Sejauh ini rekonsiliasi memang sudah diupayakan oleh pihak-pihak yang berkonflik, namun dalam upaya rekonsilaisi yang dilakukan oleh masyarakat atau kelompok yang terlibat konflik sejauh ini tidak pernah ditemukan siapa yang menjadi korban konflik dan siapa pelakunya. Dengan demikian rekonsiliasi dalam arti yang sesungguhnya belum pernah dilakukan oleh pihak-pihak yang terlibat konflik. 


\section{Agama dan Integrasi Sosial}

Dhurkheim menegaskan bahwa sumber-sumber ketegangan dalam masyarakat pada dasarnya berkembang dari heterogenitas dan individualitas yang semakin besar. Heterogenitas yang tinggi ini dapat mengendorkan ikatan bersama yang mempersatukan pelbagai anggota masyarakat. Dalam hal ini individu mulai mengidentifikasikan dirinya dengan kelompok yang lebih terbatas yang terdapat dalam masyarakat, seperti kelompok pekerjaan, profetis, etnis, ras dan agama. Ketika setiap orang atau kelompok mengejar kepentingannya sendiri dengan merugikan kesejahteraan masyarakat secara keseluruhan, maka kemungkinan terjadi konflik akan lebih besar (Johnson, 1986:169). Sementara itu di dalam kamus populer, kata integrasi (bahasa Belanda) mengandung arti menjadikan satu, penyatuan dari usaha-uaha yang terpecah-pecah (Habeyh, 1981:169). Sementara itu dalam kamus Inggris-Indonesia, kata integration mengandung arti penggabungan (Echols dan Shadly, 1984:326).

Menurut Vocabulaire Philosophique Lalande, integrasi berarti suatu usaha untuk membangun independensi yang lebih erat antara bagian-bagian dari organisme hidup atau anggota dalam masyarakat, sehingga tercipta suatu kondisi yang harmoni, yang memungkinkan terjalinnya kerjasama dalam rangka mencapai tujuan yang ditentukan bersama (Duverger, 993:340). Senada dengan hal itu pendapat Mas'oed (1991:2) adalah secara umum integrasi bisa diberi arti sebagai kondisi atau proses mempesatukan bagian-bagian yang sebelumnya saling terpisah. Proses ini berjalan melalui tahapan yang dilalui, akan merupakan landasan bagi terselenggarakannya tahapan berikutnya. Adapun Karl Deutch (1957) mengatakan bahwa integrasi harus berjalan secara damai dan berlangsung secara sukarela. Ia memandang integrasi sebagai unit-unit yang sebelumnya terpisah kemudian mampu menciptakan hubungan-hubungan independensi dan secara bersama menghasilakn unsur-unsur suatu sistem yang tidak bisa mereka hasilkan ketika mereka saling terpisah. 
Mengacu pada uraian di atas, maka seperti yang dikemukakan oleh Dhurkeim (Johnson, 1986:181-188) dalam studi tentang integrasi sosial, bahwa integrasi sosial dapat terwujud jika terjadi saling ketergantungan antara bagian yang terspesialisasikan. Dalam hal ini solidaritas didasarkan atas kesamaan dalam kepercayaan dan nilai saling tergantung secara fungsional antara masyarakat yang heterogen. Kesamaan dalam kepercayaan dan nilai saling tergantung ini akan memberi kesadaran kolektif untuk menciptakan kesatuan. Dalam hal ini Dhurkeim (David 1972:382) membedakan integrasi sosial atas 2 yaitu, integrasi normatif dalam perspektif budaya, dengan menekan solidaritas mekanik yang terbentuk melalui nilai dan kepercayaan membimbing masyarakat dalam mencapai sukses. Integrasi fungsional dengan menekankan pada solidaritas organik, yaitu solidaritas yang terbentuk melalui relasi saling tergantung antara bagian atau unsur yang tergantung dalam masyarakat.

Dalam hal ini Dhurkeim menekankan pembagian kerja dengan tidak saja mempertimbangkan faktor ekonomi melainkan faktor moral. Sementara itu Cooley (David 1972:381) membedakan integrasi atas dua yaitu, pertama, integrasi normatif, merupakan tradisi baku masyarakat untuk membentuk kehidupan bersama bagi mereka yang mengikatkan diri dalam kebersamaan itu. Kedua, integrasi komunikatif yaitu komunikasi efektif hanya dapat dibangun bagi mereka yang memiliki sikap yang saling tergantung dan mau diajak kerjasama menuju tujuan yang dikehendaki. Ketiga, integrasi fungsional, hanya akan terwujud bila anggota yang mau mengikat diri itu sungguh menyadari fungsi dan perannya dalam kebersamaan itu.

Lebih jauh Karsidi (1998:116) menggambarkan beberapa syarat bagi masyarakat heterogen untuk dapat mencapai integrasi. Dikatakan di sini bahwa integrasi hanya terjadi bila pertama, anggota masyarakat merasa tidak dirugikan bahkan keuntungan akan diperoleh lebih besar. Kedua, adanya penyesuaian paham tentang norma. Artinya tantangan dan bagaimana harus 
bertingkah laku untuk mencapai tujuan dalam masyarakat. Ketiga, norma yang berlaku harus konsisiten, untuk membentuk suatu struktur yang jelas. Integrasi sosial terjadi harus melalui tiga (3) tahapan. Pertama, akomodasi, merupakan upaya para pihk yang berbeda pendapat atau bertentangan untuk mencari pemecahan masalah atau upaya mempertemukan perbedaan atau pertentangan atau upaya menyelesaikan perbedaan melalui koordinasi. Kedua, Koordinasi merupakan perwujudan suatu bentuk kerjasama. Ketiga, asimilasi atau akulturasi merupakan kontak kebudayaan yang berlainan atau pertemuan dua kebudayaan yang lebih baik. Dalam membangun nilai harmoni akan ditemukan tahapan ini atau dengan kata lain terdapat relasi saling tergantung sehingga masing-masing pihak menyadari perannya. Dalam proses ini tidak ada in group (kita) dan out group (mereka), keduanya memiliki peran yang sama dalam membangun kehidupan yang lebih baik.

Senada dengan pendapat di atas dalam memahami konsep integrasi (Sunyoto Usman: 1995) mengemukakan bahwa integrasi adalah suatu proses ketika kelompok-kelompok sosial tertentu dalam masyarakat saling memelihara dan menjaga keseimbangan untuk mewujudkan kedekatan hubungan sosial, ekonomi dan politik. Dalam konteks tersebut integrasi bukanlah untuk menghilangkan diferensiasi, karena yang terpenting adalah kesadaran untuk memelihara dan menjaga keseimbangan untuk menciptakan hubungan sosial yang harmonis. Menurut Usman, integrasi merupakan bentuk kontradiktif dari konflik, namun meskipun demikian integrasi dan konflik bukanlah dua hal yang harus dipertentangkan. Karena integrasi bisa saja hidup bersebelahan dengan konflik, bahkan melalui konflik keseimbangan hubungan dapat ditata dan diciptakan kembali. Konsep yang ditawarkan tersebut mengisyaratkan bahwa integrasi tercipta melalui proses interaksi dan komunikasi yang intensif.

Kelompok-kelompok sosial yang berintegrasi membangun social networks dalam suatu unit sosial yang relatif kohesif. 
Prasyarat integrasi yang ditawarkan oleh Usman agar masyarakat dapat terintegrasi adalah, pertama, kesepakatan sebagian besar anggotanya terhadap nilai-nilai sosial tertentu yaitu bersifat fundamental. Kedua, saling ketergantungan diantara unit-unit sosial yang terhimpun di dalamnya untuk memenuhi kebutuhan ekonomi. Memang diakui bahwa akibat adanya perbedaan dalam pemilikan dan penguasaan Sumber Daya ekonomi dapat melibatkan terjadinya stratifikasi sosial berdasarkan (kaya, menengah, miskin). Akan tetapi dengan model pembangunan masyarakat yang menekankan saling ketergantungan ekonomi dapat mencegah kemungkinan tumbuhnya eksploitasi kelompok kaya terhadap kelompok miskin, karena masing-masing kelompok berpendapatan tadi terspesialisasi secara fungsional, sehingga ciri diferensiasi tidak terlalu sukar diseimbangkan.

Masyarakat sebagai konsep sosial menggambarkan berkumpulnya manusia atas dasar sukarela, yang tidak harus terjadi secara fisik tetapi juga berupa keterikatan dan keterkaitan batiniah (Ginandjar Kartasasmita, 1997:7). Dalam konsep masyarakat yang demikian ini ada makna kesatuan antara kebinekaan atau keanekaan (diversity) dan kekhasan atau kekhususan (uniquenness). Menurut Ginandjar "apa yang menjadi kesamaan (what is Common to all) merupakan pertanyaan mendasar setiap kali terjadi hubungan yang saling bergantung atau kerjasama yang berintikan situasi simbiosi yang mutualistis.

Situasi simbiosis yang mutualistis itu akan dapat tercipta bila elemen-elemen sosial bisa disatukan hingga membentuk suatu kekuatan yang bersifat sinergis. Kekuatan sinergis itu lahir dari proses interaksi sosial yang berlangsung secara intensif di dalam dan diantara unit-unit sosial yang ada dalam masyarakat, apakah itu keluarga, kelompok, asosiasi, golongan masyarakat (etnis dan agama) dan sebagainya. Dalam kaitan itu Ginandjar menekankan pentingnya proses interaksi sosial baik yang vertikal maupun horizontal. Pada interaksi vertikal antara pemerintah dan masyarakat harus dikembangkan dari poros "kekuasaan" menjadi 
poros "pemberdayaan". Interaksi ini harus dikembangkan menjadi interaksi dialogis. Sedangkan interaksi horizontal harus dikembangkan menjadi interaksi solidaritas dan kemitraan. Dengan terciptanya situasi demikian maka diharapkan tidak ada lagi dikatomi yang membedakan antara penduduk asli dan penduduk pendatang.

\section{B. METODE PENELITIAN}

Penelitian kualitatif pendekatan naturalistik di Kabupaten Daerah Tingkat II Situbondo, dilakukan melalui wawancara mendalam, pengamatan dan pengkajian dokumen-dokumen yang berkaitan dengan masalah penelitian. Proses penelitian dilakukan melalui interaksi dan memaknai bahasa dan tafsiran subyek penelitian. Analisa data melalui kegiatan klarifikasi data telah berhasil dikumpulkan dari berbagai sumber berdasarkan unsur-unsur fenomenologi pola interaksi antar umat beragama, hubunganhubungan sosial antar umat beragama. Kemudian di analisis hingga mengambil sebuah kesimpulan.

\section{HASIL DAN PEMBAHASAN}

Dalam konteks penelitian di Situbondo, telah terwujud integrasi dalam masyarakat pasca konflik dan hubungan baik antarumat beragama serta integrasi dalam masyarakat dapat terpelihara dalam jangka waktu yang lama hingga saat ini. Masyarakat menggunakan modal sosial untuk mewujudkan integrasi di Situbondo. Integrasi dalam masyarakat dilakukan dengan menggunakan modal sosial yaitu, : (1) bahasa sebagai alat komunikasi warga masyarakat sehari-hari (2), ketergantungan secara fungsional dalam pekerjaan dan ekonomi (3), kegiatan sosial, gotong royong dan tolong menolong dan (4) kegiatan keagamaan yang dirayakan bersama oleh warga masyarakat (5) Kultur Madura 


\section{Pemakaian bahasa lokal dalam kehidupan sehari-hari}

Bahasa mempunyai kekuatan integratif untuk melakukan interaksi antara satu kelompok dengan kelompok lainnya dalam kehidupan sehari-hari. Kesamaan dalam pemakaian bahasa telah menciptakan hubungan yang saling berdekatan antara warga masyarakat yang berbeda agama dan etnis. Dalam konteks Situbondo bahasa yang digunakan adalah bahasa Madura. Bahasa Madura adalah bahasa lokal yang digunakan oleh semua warga masyarakat Situbondo baik penduduk asli Madura maupun nonMadura di samping bahasa Indonesia.

Berkomunikasi dengan bahasa lokal sangat mempengaruhi kedekatan emosi dalam pergaulan dan hubungan dengan pihak yang diajak berkomunikasi. Sebaliknya apabila seseorang memakai bahasa Indonesia dalam berkomunikasi hubungan menjadi kurang akrab, kaku dan sangat formal. Bahkan pemakaian bahasa Indonesia dalam berkomunikasi bisa menjadi tanda bahwa yang sedang berkomunikasi adalah pendatang baru atau orangorang yang sedang berkunjung di daerah tersebut. Di tempattempat lain misalnya seperti Jember, Kraksaan dan Probolinggo yang adalah daerah-daerah pantura Jawa Timur lainnya, meskipun bahasa Madura digunakan, tetapi bukan merupakan bahasa sehari-hari yang digunakan untuk komunikasi dalam pergaulan dalam masyarakat seperti yang terjadi di Situbondo, namun hanya digunakan di pasar-pasar atau dalam keluarga Madura saja.

Sementara bahasa yang digunakan sehari-hari menggunakan bahasa Indonesia dan campuran bahasa Jawa dan Madura. Di Situbondo, bahasa Madura sangat melekat dalam kehidupan masyarakat sebagai alat komunikasi di berbagai waktu dan mendekatkan hubungan secara emosi, meskipun berbeda agama atau bukan berasal dari suku Madura. Dengan demikian bahasa Madura sebagai alat komunikasi sehari-hari dapat menjadi alat perekat dan kekerabatan dalam masyarakat. 


\section{Saling ketergantungan dalam hal pekerjaan dan Ekonomi}

Dalam kehidupan sehari-hari, hubungan saling tergantung secara fungsional antara etnis Cina dengan etnis Madura Situbondo terjadi pada bidang pekerjaan dan ekonomi, yaitu ketergantungan secara fungsional antara pemilik toko atau swalayan dengan para karyawannya. Ketergantungan semacam ini telah menciptakan hubungan saling membutuhkan dan menjadi alat perekat sosial. Hubungan yang saling bergantung ini dapat mengikat dalam kebersamaan, dijauhkan dari perbedaan agama dan etnis. Dalam hal ini kedua belah pihak yang berbeda etnis dan agama saling membutuhkan, dan akan mengalami kesulitan jika ditinggalkan oleh pihak yang lain.

Saling ketergantungan ini terjadi dalam hal hubungan kerja, etnis Cina di Situbondo yang mayoritas beragama kristen sangat besar peranannya di bidang ekonomi. Perekonomian masyarakat Situbondo banyak didukung oleh etnis Cina terutama dalam usaha dagang seperti toko sembako, percetakan, bangunan, dan lain sebagainya. Dalam hal ini mereka berusaha untuk tetap menjalin hubungan baik dengan etnis Madura. Hubungan baik ini diwujudkan melalui sikap dan prilaku etnis Cina terhadap karyawannya yang hampir seluruhnya berasal dari etnis Madura beragama Islam.

Dalam kehidupan sehari-hari dan hubungan kerja para karyawan dianggap sebagai saudara dan dibutuhkan dalam usaha dagang yang dijalankan etnis Cina. Agama tidak menjadi masalah dan penghalang dalam pergaulan dan kerjasama di wilayah ini. Toleransi dan sikap mengharagai agama Islam diwujudkan dengan menyediakan tempat sholat dan atau Musholla bagi karyawan yang beragama Muslim, sehingga mereka bisa melakukan shalat pada waktu-waktu tertentu dengan bebas.

Dalam hal ekonomi, beberapa pemilik toko-toko swalayan di Situbondo menyediakan kupon potongan harga sebesar $20 \%$ bagi para konsumen. Dalam hal ini semua anggota NU, santri, kyai dan warga masyarakat Situbondo mempunyai kartu potongan untuk keperluan belanja di toko swalayan milik etnis Cina. Kebiasaan 
yang terjadi di Situbondo ini menjadi sarana perekat sosial dan hubungan yang saling tergantung diantara anggota masyarakat.

Dalam kehidupan sehari-hari selama bertahun-tahun telah terjadi penguasaan bidang ekonomi oleh etnik Cina di Situbondo. Keadaan dan kondisi yang demikian ini bukan tidak mungkin akan menimbulkan terjadinya gejolak sosial. Dalam hal ini faktor eksternal, yaitu kesenjangan sosial cukup dirasakan oleh warga masyarakat. Para pendatang, non Islam dalam hal ini etnis Cina memiliki kemampuan ekonomi yang baik, sedangkan warga pribumi, Islam etnis Madura berada pada ekonomi bawah.

Selain itu ada anggapan yang mengatakan bahwa kaum atau golongan tertentu sejak jaman kolonial telah lama menikmati fasilitas dan selalu mendapatkan privilage akan sangat rentan menjadi pemicu kecemburuan sosial dan emosi warga masyarakat pribumi, beragama Islam. Namun selama ini untuk mencegah timbulnya gejolak sosial etnis Cina cukup tanggap mengantisipasi hal tersebut sehingga gejolak warga pribumi dapat diredam dan diatasai.

Nampaknya etnis Cina cukup tanggap mengantisipasi hal tersebut sehingga gejolak sosial yang bersumber pada kesenjangan ekonomi masih bisa diatasi dan dicegah. Sebagaimana yang ditegaskan Ginandjar "apa yang menjadi kesamaan (what is Common to all) merupakan pertanyaan mendasar setiap kali terjadi hubungan yang saling bergantung atau kerjasama yang berintikan situasi simbiosis yang mutualistis. Situasi simbiosis yang mutualistis itu akan dapat tercipta bila elemen-elemen sosial bisa disatukan hingga membentuk suatu kekuatan yang bersifat sinergis. Kekuatan sinergis itu lahir dari proses interaksi sosial yang berlangsung secara intensif di dalam dan diantara unit-unit sosial yang ada dalam masyarakat, apakah itu keluarga, kelompok, asosiasi, golongan masyarakat (etnis dan agama) dan sebagainya. 


\section{Perkumpulan sosial, partisipasi, solidaritas dan kekerabatan}

Yang dimaksud partispasi, solidaritas dan kekerabatan dalam hal ini adalah keikutsertaan dan keperdulian warga masyarakat yang didasari oleh perasaan persaudaraan sebagai sesama masyarakat Situbondo. Salah satu kelompok agama biasanya memprakarsai untuk menunjang kegiatan sosial tertentu.

Selain itu keikutsertaan individu masing-masing kelompok agama untuk menunjang berbagai kegiatan sosial yang diprakarsai pemerintah juga turut mendukung terbangunnya partisipasi, solidaritas dan kekerabatan dalam masyarakat. Indikator terpeliharanya partisipasi, solidaritas dan kekerabatan nyata dalam keikutsertaan orang-orang dari kelompok agama yang berlainan dalam kegiatan selamatan, tolong menolong yang diprakarsai kelompok agama; perkumpulan-perkumpulan sosial tertentu dalam kegiatan gotong-royong; perkumpulan sosial dan perayaan hari-hari raya keagamaan.

Melakukan kegiatan bersama merupakan kebutuhan setiap individu sebagai mahkluk sosial. Kegiatan tolong menolong antar tetangga dan warga masyarakat yang lebih luas adalah salah satu sarana kekuatan integratif sosial di daerah Situbondo dan sekitarnya. Kegiatan gotong royong dan saling membantu ini nampaknya sudah merupakan tradisi yang melekat pada masyarakat Situbondo. Untuk urusan tolong menolong atau gotong royong ini etnis Madura sebagai mayoritas penduduk dapat dikatakan pelopornya. Dengan didukung karakter suka bergaul, terbuka dan mudah akrab dengan orang lain maka urusan tolong menolong bukalah hal yang sulit bagi mereka orang Madura.

Selain itu etnis Madura juga dikenal sebagai etnis yang ringan tangan dan suka membantu jika ada kenalan, tetangga bahkan siapa saja yang membutuhkan bantuannya. Kegiatan saling tolong menolong ini bahkan dilakukan tanpa diminta, tetapi terjadi secara getok tular. Mereka akan datang dan segera memberi bantuan meskipun kegiatan itu harus dilakukan selama dua sampai tiga hari. Baiasanya para wanita membantu didapur, 
sedangkan laki-laki memasang tenda, mengangkat kusi dan berbagai urusan luar. Mereka rela mengorbankan tenaga dan waktunya hanya untuk membantu tetangga yang punya hajatan. Bahkan mereka lebih memilih untuk tidak masuk bekerja demi membantu tetangga atau kerabat yang sedang mempunyai hajatan.

Budaya gotong royong ini sampai sekarang masih melekat di masyarakat Situbondo. Selain kegiatan tolong menolong dan gotong royong, kegiatan sosial seperti perkumpulan-perkumpulan sosial baik secara rutin diselenggrakan oleh kelompok Kelurahan, Kecamatan, Rukun Warga (RW) sampai Rukun Tetangga (RT). Dalam perkumpulan-perkumpulan sosial tersebut warga masyarakat Situbondo biasanya bertemu satu bulan sekali untuk mengadakan pertemuan-pertemuan Pembinaan Kesejahteraan Keluarga (PKK), Arisan, dan kegiatan-kegiatan sosial lainnya. Dalam pertemuan-pertemuan tersebut semua agama dan etnis lain berkumpul sebagai satu komunitas yang saling mendukung dan bisa berinteraksi dengan baik. Perbedaan agama tidak pernah mempengaruhi keakraban dan hubungan sosial yang sudah terjalin diatara mereka.

Dari pengalaman Situbondo, masyarakat sebagai konsep sosial menggambarkan perkumpulan manusia atas dasar sukarela yang tidak harus terjadi secara fisik tetapi juga keterikatan dan keterkaitan secara batiniah (Kartasasmita,1997). Dalam konsep masyarakat demikian ada makna kesatuan antara kebinekaan atau keanekaan (diversity) dan kekhasan atau kekhususan (uniquenness). Hubungan yang saling bergantung atau kerjasama yang berintikan situasi simbiosis yang mutualistis. Situasi simbiosis ini akan terjadi bila elemen-elemen sosial bisa disatukan hingga membentuk satu kekuatan yang bersifat sinergis.

Kekuatan sinergis tersebut lahir dari proses interaksi sosial yang berlangsung secara intensif di dalam dan di antara unit-unit sosial yang ada dalam masyarakat apakah itu keluarga, kelompok asosiasi, golongan masyarakat, etnis, agama dan sebagainya. 
Dalam konteks Situbondo menjadi penting artinya memelihara hubungan sosial yang didasari kebutuhan bersama yang saling menguntungkan.

\section{Perayaan Hari Besar Keagamaan}

Perayaan hari besar agama yang dilakukan oleh kelompok agama tertentu dan didukung kelompok agama yang lain merupakan bentuk toleransi sosial yang berhasil diwujudkan umat beragama di Situbondo pasca konflik. Toleransi sosial yang dimaksud di sini adalah bersedianya kedua belah pihak yang berbeda agama saling mengakui dan menghormati pendirian satu sama lain.

Indikatornya meliputi, menerima dan menghargai nilai-nilai, pandangan, pendapat, kepercayaan umat beragama yang berbeda walaupun berbeda ajaran atau doktrin yang diyakininya; kesadaran diri untuk bersedia berkorban demi pemeluk agama lain, dalam hal ini pengorbanan yang berkaitan dengan masalahmasalah sosial merupakan bentuk-bentuk toleransi sosial. Melalui silaturahmi, pengajian dan kegiatan agama lainnya warga masyarakat berusaha untuk tetap menjaga dan mempertahankan integritas dan toleransi sosial di Situbondo.

Masyarakat Situbondo pada dasarnya sangat memperhatikan perayaan-perayaan hari besar keagamaan seperti, Idul Fitri, Idul Adha, Isra'miraj, Maulud Nabi dsb. Hari-hari besar keagamaan ini menjadi alat integratif antar warga masyarakat. Sedangkan untuk mempertahankan dan memelihara ikatan sosial dengan warga masyarakat yang berbeda agama dilakukan dengan cara saling mengundang dalam kegiatan keagamaan, atau acaraacara keagamaan tertentu seperti misalnya syukuran setelah pulang dari ibadah haji dan lain sebagainya.

Bagi masyarakat Situbondo, perayaan Natal yang diperingati umat Kristen juga menjadi bagian dari masyarakat, karena umat kristen selalu mengundang agama lain dalam memperingati Natal, khususnya dalam perayaan-perayaan Natal. Kegiatan keagamaan berupaya perayaan-perayaan tersebut merupakan sarana membagun kehidupan umat beragama yang saling menghormati 
dan menghargai. Demikian juga dengan Idul Fitri bukan lagi menjadi perayaan umat Islam saja tetapi menjadi perayan semua umat beragama, karena seluruh warga masyarakat Situbdondo turut bersukacita dalam perayaan-perayaan idul fitri tersebut.

Biasanya mereka melakukan kunjungan ke rumah-rumah tetangga atau kerabat yang merayakan Idul Fitri. Umat beragama non-Islam biasa berkunjung ke pondok-pondok pesantren untuk bersilaturahmi dengan kyai dan para santri. Sebagaimana dijelaskan di atas bahwa peranan Kyai sangat besar dan dihormati oleh masyarakat Situbondo. Menjadi sebuah kewajiban yang melekat dalam warga masyarakat Situbondo untuk datang ke rumah kediaman kyai setiap hari raya Idul Fitri. Dengan demikian Idul Ftri menjadi perayaan dan kegembiraan seluruh warga masyarakat, baik muslim maupun non-muslim.

\section{Kultur Madura}

Kultur masyarakat Madura cendrung memiliki sikap terbuka, blakblakan atau berterus terang dalam berbagai hal. Relasi dan komunikasi antar warga masyarakat ditandai dengan keterbukaan dan keterus terangan, penggunaan bahasa Madura sebagai alat komunikasi sehar-hari merupakan tanda hubungan dekat antara seorang dengan yang lain. Kebersamaan dan kekerabatan ditunjukkan dengan cara-cara yang wajar, alamiah dan tidak dibuat-buat. Hubungan kekerabatan nampak dalam kehidupan sehari-hari dalam sikap yang saling peduli dan membantu jika ada tetangga atau kerabat mengalami kesulitan dan masalah. Hubungan yang dekat ini mudah sekali dibangun, hanya dengan kehidupan sosial sehari-hari di tengah masyarakat seperti ngobrol bersama, jaga ronda di pos kamling kampung, kerja bakti, perayaan-perayaan Hari Ulang Tahun (HUT) Kemerdekaan RI dan lain sebagainya. Tidak sulit bagi orang Madura menjadi dekat dengan dan akrab dengan orang lain meskipun baru mengenalnya.

Karakter masyarakat Situbondo baik langsung maupun tidak langsung sangat berpengaruh dalam hubungan antar umat 
beragama. Dalam konteks Situbondo, kultur Madura adalah kultur yang paling dominan. Masyarakat Situbondo sejak lama dikenal sebagai masyarakat yang mempunyai karakteristik religius bahkan cenderung fanatik dalam beragama, dan taat beribadah. Bagi orang Madura memberikan collective sentiment, melalui upacara-upacara ibadah dan ritualnya. Keharusan beragamalah yang membuat orang Madura menjadi sebuah masyarakat dengan membentuk organisasi sosial berdasarkan pada agama dan otoritas para ulama (Kyai). Budaya dan sifat masyarakat Madura yang energik penuh gairah, percaya diri, pemberani, extrovert, terus terang serta memiliki keperdulian dan gotong royong yang amat tinggi sangat berpengaruh positif bagi kehidupan sosial sehari -hari.

\section{Peran Agama dalam Integrasi}

Agama yang dimaksud di sini adalan institusi atau lembaga agama, pimpinan atau tokoh agama dan umat. Dalam kapasitasnya masing-masing ketiga unsur ini turut menyumbang terwujudnya perdamaian dan integrasi dalam masyarakat pasca kerusuhan. Kultur agama Islam sangat mewarnai kehidupan masyarakat Situbondo, hal tersebut disebabkan karena peran NU, ulama dan pesantren sangat besar dan ternama di Situbondo.

Bahkan beberapa pesantren mempunyai pengaruh yang besar di masyarakat seperti Walisongo, Sletreng, Salafiah Safiah dan lain sebagainya. Pesanten-pesantren ini turut meramaikan dan memberi power spiritual di Situbondo. Secara struktural kokohnya pengaruh ulama tidak dapat dilepaskan dari perannya sebagai cultural broker, yakni keyakinan untuk menghubungkan tatanan keagamaan dan faktor lokal. Kyai atau ulama sering disebut sebagai agent of change dalam masyarakat. Bahkan sering disebut sebagai informal leader yang kerap diberi kepercayaan oleh pemerintah sebagai salah satu pembawa pesan-pesan pembangunan untuk masyarakat. Program-program pemerintah dapat berhasil $100 \%$ dan mendapat dukungan penuh dari warga masyarakat apabila telah direstui dan didukung oleh kyai. 
Peran ulama di bidang keagamaan tidak dapat dipisahkan dengan peran mereka di tengah masyarakat. Berpusat dari perannya sebagai guru dan ahli agama para ulama di Situbondo seringkali memainkan peran penting dalam kehidupan sosial, kemasyarakatan dan politik. Pandangan bahwa Islam tidak memisahkan antara agama dan negara ikut mendorong munculnya gejala ini.

Di samping itu sistem sosial di sekitarnya juga ikut mendukung dalam hal ini. Para ulama di Situbondo memperoleh tempat yang sangat terhormat di Situbondo dan sangat berpengaruh di Masyarakat. Nasehat dan petunjuknya sangat didengar dan diperhatikan oleh seluruh warga masyarakat juga yang beragama non Islam. Hal ini juga berkaitan dengan watak Situbondo yang religius, sehingga kyai menempati posisi yang terhormat di mata masyarakat. Nasehat dan petunjuknya bisa dijadikan acuan dalam masyarakat, terutama jika warga masyarakat hendak melakukan suatu kegiatan. Suara kyai didengar, perintahnya dipatuhi secara penuh, karena selain dianggap mempunyai pengetahuan di bidang agama juga dipandang sebagaiorang yang memahami keagungan Tuhan dan rahasia alam lainnya. Bahkan kyai juga menjadi tempat mengadu untuk mencarikan jalan keluar bagi problematika yang dihadapinya, yang tidak hanya terbatas pada masalah agama tetapi juga persoalan hidup lainnya. Pemerintah juga sangat menghargai kyai dan melibatkan di berbagai sektor-sektor tertentu dalam pemerintahan, terutama kyai-kyai "vokal" dalam berbicara.

Sumber kewibawaan kyai utamanya adalah kewibawaan moral yang muncul dari superioritasnya di bidang keagamaan. Kyai dianggap umat sebagai orang yang memiliki pengetahuan keagamaan tinggi dan memiliki kekuatan spiritual yang melebihi kebanyakan orang. Kyai juga mempunyai relasi yang kuat dengan pemerintah dan pusat-pusat kekuasaan di luar, seperti dengan NU, PKB, LSM yang merupakan basis kekuasaan beberapa orang kyai. Dalam konteks masyarakat situbondo, para kyai sangat dihormati 
oleh orang Madura, kedudukan kyai sama dengan penguasa karena dianggap memiliki kekuatan spiritual. Dalam sejarah Madura kekuatan para kyai menjadi semakin terinstitusikan bersamaan dengan menebarnya tarekat dan pesantren-pesantren di masyarakat. Dari sejarah Madura tampak bahwa para kyai telah melestarikan dirinya bukan hanya sebagai pemimpin informal, tetapi juga sebagai institusi kritis terhadap kekuasaan yang ada.

Dengan kekuatan dan kewibawaan yang dimilki Kyai maka ketika terjadi konflik dalam masyarakat, maka peranan kyai sangat besar untuk dapat menghentikan dan menyelesaikan konflik tersebut. Perintah, petunjuk dan nasehat kyai akan sangat didengar dan diperhatikan oleh warga masyarakat. Di sinilah peranan pimpinan agama, khususnya ulama, kyai sangat besar pengaruhnya bagi penyelesaian konflik dan membangun rekonsiliasi pada piha-pihak yang terlibat konflik.

Penyelesaian konflik dapat dilakukan melalui mediasi. Dalam hal ini pemimpin agama duduk bersama untuk saling mendengarkan apa yang menjadi permasalahan masing-masing agama dan dicarikan alternatif solusinya secara bersama-sama pula. Melalui pertemuanpertemuan ini telah tumbuh diskusi dan pengambilan keputusan atau kesepakatan penting antara keduapihak yang berkonflik untuk langkah ke depan. Melalui diskusi antar lembaga ini masing-masing agama dapat mengetahui kekurangan masing-masing dan selanjutnya dapat memperbaiki kesalahannya sendiri ke arah yang lebih baik demi untuk kepentingan dan kebaikan bersama. Langkah seperti ini dilakukan untuk menghentikan dan atau mencegah konflik yang berkepanjangan.

\section{Menuju Rekonsiliasi}

Dalam banyak kasus konflik di berbagai wilayah di Indonesia nampaknya rekonsiliasi secara menyeluruh belum pernah terjadi. Artinya upaya untuk mencapai kesepakatan berdamai akibat masa lalu yang kelabu masih merupakan proses yang masih terus menerus harus diperjuangkan. Dalam kasus konflik bernuansa 
agama di Situbondo, rekonsiliasi yang sesungguhnya belum terwujud. Ketika kita mengacu pada pengertian rekonsiliasi maka ada beberapa hal yang mensyaratkan terjadinya rekonsiliasi. Pertama, perlu ada pengakuan hukum dari masyarakat terhadap pelaku dan korban. Kedua, keadilan harus ditegakkan berarti dilaksanakan restribusi (sanksi hukum) terhadap pelaku dan restribusi (pemulihan) terhadap korban. Ketiga, adanya pemisahan antara pengampunan dan kepastian hukum. Keempat, bila hukum positif yang berlaku tidak memiliki pasal-pasal yang mengatur dan memberi sanksi pelanggaran, penyelesaian harus mengacu ke prinsip epikeia (yang benar yang adil). Dalam hal ini masalah resitusi (pemulihan) terhadap korban tidak dapat diabaikan karena hal ini merupakan aspek keadilan.

Dalam kasus-kasus konflik di Indonesia, rekonsiliasi belum pernah dilakukan secara benar, hal ini perlu menjadi perhatian semua pihak khususnya lembaga hukum untuk mengupayakan rekonsiliasi pada setiap selesai konflik. Dalam kasus konflik di Situbondo belum terjadi rekonsiliasi dalam arti yang sesungguhnya, namun baru dilakukan upaya-upaya untuk mencapai perdamaian dan pemulihan hubungan keduapihak yang terlibat konflik.

Saling ketergantungan merupakan prasyarat agar keduabelah pihak yang terlibat konflik dapat menyatu kembali. Ketergantungan dalam hal ini bisa melingkupi berbagai aspek kehidupan. Namun demikian biasanya ketergantungan dalam memenuhi kebutuhan ekonomi merupakan hal yang dapat mencegah terjadinya eksploitasi antara golongan yang satu terhadap golongan yang lain karena masing-masing kelompok berpendapatan terspesialisasi secara fungsional. Hal ini didasari oleh adanya penguasaan sumber daya ekonomi yang menyebabkan adanya stratifikasi sosial dalam masyarakat berdasarkan kaya, menengah dan miskin (Usman,1995). Akibat adanya pebedaan tersebut akan terjadi konflik antar golongan. Untuk dapat mencapai kesepakatan dalam rangka memperbaiki 
hubungan yang terganggu akibat konflik dibutuhkan waktu dan proses yang tidak pendek.

\section{KESIMPULAN}

Dalam banyak kasus konflik sosial bernuansa agama pada dasarnya disebabkan oleh banyak faktor yang mempengaruhi baik, ekonomi, politik dan budaya. Disamping beberapa faktor penyebab konflik, faktor agama juga bisa menjadi penyebab terjadinya konflik dalam masyarakat yang menyebabkan disintegrasi dalam masyarakt. Namun demikian konflik bukan tidak bisa diselesaikan sejauh ada keinginan dan usaha bersama, terutama pihak yang terlibat konflik untuk mewujudkan perdamaian tersebut.

Dalam kasus Situbondo umat beragama Islam dan Kristen berhasil menyelesaikan konflik. Peran kyai, pendeta dan pimpinan agama sangat besar dalam penyelesaian konflik selain itu juga upaya-upaya yang dilakukan oleh keduaumat beragama yang terlibat konflik itu sendiri. Pasca Konflik telah dibuat kesepakatan dan upaya-upaya membangun kehidupan antarumat beragama yang lebih kondusif sehingga integrasi dapat dibangun di Situbondo.

Penyelesaian konflik dan integrasi sosial dalam masyarakat dapat diupayakan melalui kearifan lokal yang dimiliki oleh warga masyarakat Situbondo. Melalui modal sosial ini masyarakat menyadari bahwa mereka pada hakekatnya adalah saudara, kerabat yang saling membutuhkan dan tergantung. Sebagai sesama warga masyarakat yang tinggal di Situbondo kultur Madura berhasil merekatkan hubungan kedua umat beragama dalam tataran lokal dan nasional.

Dari hasil penelitian menunjukkan bahwa pihak yang paling berperan dalam penyelesaian konflik adalah masyarakat lokal yang terlibat konflik itu sendiri, dan bukan datang dari pihakpihak luar yang tidak terlibat konflik seperti militer dan pemerintah. Nilai-nilai lokal, kultur masyarakat setempat sangat besar artinya bagi terwujudnya perdamaian. Kearifan dan kultur 
masyarakal lokal yang terlibat konflik merupakan kekuatan integratif yang dapat menjadi pintu masuk dalam mewujudkan integrasi dalam masyarakat yang mengalami kerusakan akibat terjadinya pertikaian. Dalam kasus ini masyarakat Situbondo berhasil menggunakan modal sosial berupa kekuatan kultur sebagai sarana menciptakan kehidupan bersama yang harmonis pasca kerusuhan.

\section{DAFTAR PUSTAKA}

Bogdan, R. C. and Biklen, S. R. 1982. Qualitative Research for Education. Boston Allyn and Bacon Inc.

Dahrendorf, R. Terjemahan Ali Mandan. 1986. Konflik-konflik dalam masyarakat Industri. Jakarta CV Rajawali.

Erns, H. 1971. The Study Regional Integration, dalam Mohtar Mas'oedd. Handouts "Dunia Ketiga dan Politik". Program Pascasarjana UGM, Yogyakarta.

Victor, I. T. 1998. Pluralisme Agama dan Problema Sosial. Jakarta, Cidesindo Knopp Bilken. 1991. Metodologi Penelitian Kualitatif lebih menjamin masalah sosial di Indonesia, Kompas 15 Juni 1998.

Johnson, D. P. 1986. Teori Sosiologi Klasik dan Modern Jilid I di indonesiakan oleh Robert MZ Lawang. Jakarta Gramedia.

Miles M.B and Huberman, A. M. 1984. Qualitative Data Analysis. California:Sage Publication.

Nasikun. 1995. Sisitem Sosial di Indonesia. Jakarta Raja Grafindo Persedia.

Nasution. 1988. Metode Penelitian Naturalistik Kualitatif. Badung Tarsito

Pranomo, M. B. 1988. Stereotype Etnik, Asimilasi dan Integrasi Sosial. Grafika Kita. Jakarta. 
Robertson, R. 1988. Agama dalam Analisa dan Intrepetasi Sosiologis. Penerjemah Achmad F. S. Jakart. CV Rajawali.

Saiffudin, A. F. 1986. Konflik dan Integrasi. Pubahan Faham dalam agama Islam. Jakarta CV Rajawali.

Usman, S. 1995. Integrasi dan Ketahanan Nasional. Sumbangan sosial terhadap ketahanan nasional, penyunting: Ichlasul Amal dan Armaidy 